\title{
Fragments and Coherence: Celebrity Femininities in Cover Story of Kartini Magazine
}

\author{
Aquarini Priyatna \\ Universitas Padjajaran \\ Email: aquarini@unpad.ac.id
}

\begin{abstract}
This paper discusses the notion of femininity values assigned to women and considered to be the sign of womanhood. More specifically, it discusses the representation of female celebrity femininity as staged in their auto/biographical practice in women's magazines Kartini. The paper also analyses how celebrity auto/biographical practices constitute what can be considered as feminine narrative [structure] that is fragmented yet coherent. Focusing on the issues of time and space, I argue that autobiographical practice in print media such as women's magazines, despite its popular terrain, displays a complex structure of fragments and coherence in representing female celebrities as both public persona and private persons. Likewise, the alternative form of auto/biographical practices appearing in women's magazines suggest that more embracing critical accounts of contemporary auto/biographical practices are necessary.
\end{abstract}

Keywords: auto/biographical practices, Cover Story, femininities, Indonesian female celebrities, women's magazines

\section{INTRODUCTION}

This paper analyses a form of self-narrative in women's magazines, which I argue to be a popular form of auto/biographical practice in popular culture. I am using the term "auto/biographical practices" as it is appropriately applied to the new forms of autobiographical practices being generated in Indonesian mass culture by these female celebrities. As Bakhtin (1981: 132) asserts "there could not in principle be any difference between the approach one took to another's life and to one's own, that is, between the biographical and the autobiographical point of view." The use of the term "auto/biographical", following Marcus (1994) suggests this collapse between autobiography and biography as well as the blurring of various domains that establish auto/ biographical subjects.
This paper particularly focuses on women's magazine in Indonesia, namely Kartini. Amidst the highly expanding media for women, both printed and online, Kartini magazine is still arguably among the longest standing women's media. Kartini is among the first Indonesian women's magazine whose scope remains to cover the upper middle class women as well as housewives (Kartajaya, Yuswohady, Christynar, \& Darwin, 2005: 133). It tackles various, albeit stereotypical "women's issues", from health, to cooking, from beauty and children and fashion. Kartini used to be a very powerful magazine until recently, especially since the booming of media and other forms of women's media, including the cheaper tabloids in 1999 (Kartajaya et al., 2005). While Kartini can no longer be considered to the most powerful magazine, it is still surviving. The 
new market leader, if not the most powerful one, is now Femina, which, according to Rhenald Kasali (1998: 153), continues to maintain its position to be best magazine in its class, not only through its advertising turnover, which amounted to 19 billion in the first semester of 1997, but also through its high circulation. While Femina readers are more likely to be young professionals, independent, even when they are also housewives (Kasali, 1998). The target readers continue in that segment even today as stated in their website that the target readers of Femina "are active women 25-35 years old; belong to the SES AB class; care about their appearances and avid trend followers; have high social mobility; are financially secure" (http:// www.feminagroup.com/media.kit/001/6). Kartini, however, is targeted more towards "Women who really cares about their family and also social issue both local and international" (http://trinaya. $\mathrm{com} /$ kartini.html). The different target readers implicate different issues, concerns and interests dwelled upon in the content as well as different ways of communicating them, this paper will show how the magazine constructs the portrayal of femininities of the female celebrities featured in their Cover Story.

Within the context of popular culture, celebrities are significant part of women's magazines. They exist and play different roles not only pertaining to their profession but also to their personal lives. Their fashion style, their romantic lives, their ambitions, and their whole ups and downs can become issues of interests elaborated in women's magazines. In fact celebrity life stories are arguably among the most sought-after segment in women's magazines.

Even though the samples taken for analysis in the paper are dated back to 2000-2006, similar patterns remain in the magazines published in the recent years. Basically, in terms of length, there are two forms of auto/biographical practice in women's magazines: namely the short one and the serial. The short one is often referred to as "Cover Story", namely the story about the woman/women featured in the magazine cover. Kartini names this feature "Cover Story", for comparison, Femina calls it Cerita Sampul, which literally means cover story. This feature generally takes up only one to three pages and only talks about a certain moment of the celebrity's life, mostly around the time the photo shot is taken for the cover. The plot of this narrative is highly dependent on issues of relationships in the way that it can even be read as a romantic story. Consequently, this space for talking about relationship can also be argued to be feminine in its nature (Jelinek, 1998). I have discussed this tendency for female celebrity auto/ biography to be "feminine" in its inclination for discussing private and domestic relationship elsewhere.

Apart from romantic relationships, beauty and body are among important feminine issues that frequently appear in celebrity auto/biographies. Although discussion about career does emerge, it is mostly connected to how it affects the relationships with their close circle, particularly their romantic partner. I choose to discuss Kartini's "Cover Story" particularly based on its stability. As a feature, the Cover Story in Kartini has a fixed name and pattern of narration, compared to the same auto/biographical feature in Femina. Cover story as a feature appears in Kartini in all the years covered in this research, namely $2000-2006$. For comparison, the short auto/biographical practice in Femina often appears under different "features" despite the lack of any distinctive differences among them. The frequent names for the similar feature are Cerita Sampul (Cover Story), Omongomong (Chit chat), Selebriti (Celebrity), and Halo (Hallo). Thus, it sustains some kind of stable narrative structure.

Two key concepts are used as the frameworks in the discussion of the texts selected. The first one is the theory of "Chronotope" derived largely from Bakhtin (1981) and the concept of beauty proposed by a number of feminist scholars, particularly Davis (1995) and Bordo (1995). The framework is used to support my argument that female celebrities are presented in Cover Story as stable and unchanged despite the change of time and places having taken place. The Cover Story present female celebrities as living in some kind of ideal life and that they continue to live a happy and meaningful life. The same is also argued in the context of their physical beauty and body. Cover Story focuses on the beauty and their ideal body of the female celebrities featured in a way that they are presented as eternally young and beautiful as 
well as having ideal slender body.

Literally, chronos means time, and Topos means space. This concept is important as I argue that Cover Story employs repetitive strategy that moves the character from one chronotope to another, traversing the time from the past to the historical/biological and biographical "present" and back. The same also applies to the space where the celebrity biographical subject moves from public space to domestic space rendering the distortion of the two domains. As Bakhtin (1981: 132) asserts:

It is fully understandable that in such a "biographized" individual (in such an image of a man) (sic) there was not, nor could there be, anything intimate or private, secret or personal, anything relating solely to the individual himself, anything that was, in principle, solitary. Here the individual is open on all sides, he is all surface, there in him nothing that exists "for his sake alone," nothing that could not be subject to public or state control and evaluation. Everything here, down to the last detail, is entirely public.

This is even more so in the contemporary celebrity culture where one's private life is heavily publicized in the ways that a celebrity's intimate life can no longer be kept to herself as it has become public knowledge. Stories about celebrities are everyday information shared by a large audience worldwide. The story about a celebrity's break up, marriage, divorce is a story that has proven to be of great interest to both the enthusiasts and the apathies. Once a person's life is written, even in its specific temporal fragment, her life is public and the space where private/public as well as feminine/ masculine domains reside are effectively traversed. Interestingly, although celebrity's life is often narrated and represented by fragmented segments, the main plot of celebrity narrative is seemingly linear, telling the story chronologically in terms of the historical/biological life of the celebrity.

Despite the general chronological plot, the introduction to the feature is almost always a flashback and it is generally starts from a certain moment in the celebrity's life considered to be the trajectory of her success and achievement, or extraordinariness. There are also interceptions to the plot by bringing the present biographical subject to elaborate a certain moment in her past life. In this way the past selves are brought to the present or the present selves bridge the past selves to the present. This justifies why the concept of chronotope in significant in understanding the narratives of life, including those in popular culture. According to Shumway (1994: 157),

The chronotope is the time/space continuum that gives shape to a novel, directing and in some ways even generating its existence. The chronotope functions, we might say, as a form of setting for the novel. But more than merely a device to locate the plot within a specific time and place, the chronotope actively works to shape and create the plot itself, becoming, in the end, a formal, as well as a thematic, feature of the plot.

In the narratives examined, the biographical subject is transported from her fame and celebrity status to her pre-fame space. Then the plot moves forward in a mode of retracing her way to the top in terms of her career, and finding and being united with the man that she loves. This is what Bakhtin (1981) argues as the two biological moments where there is an empty space, in which the auto/ biographical subject remains the same; she is as beautiful and young as she has always been portrayed despite the many adventures, obstacles, and battles she has had to endure.

In addition to her personal life, beauty has been considered an important issue to take up within the study of gender, particularly the study that focuses on popular culture. Feminists have taken different stances in perceiving beauty and how beauty contributes greatly to the construction of femininity. Some feminist scholars argue that beauty is a form of oppression in a way that any process of beautification and any attempt to look attractive is perceived as a form of objectification, which largely refers to what is called a "system of cultural beauty norms" (Davis, 1995: 50). Referring to various other researches, Davis 
explain that by this norm, women are demanded to show youthful beauty and other standards that are virtually impossible. Beautiful women are those who have "slender but voluptuous shapes, faces unmarked by the passage of time, and most of all, appearance in keeping with the conventions of upper-class, Western femininity" (Davis, 1995: 50). This demands imply works and sacrifices. As beauty is highly upheld, women might not be able to escape the demands. This leads to the understanding and acceptance that beauty ideals is a form of endless project of cultivation that works well within capitalist society. Beauty requires consumption. In other words, as Davis rightly writes, in talking about beauty, "one feature remained constant: namely that beauty was worth spending time, money, pain, and perhaps life itself" (Davis, 1995: 41). Working on one's appearance thus is increasingly seen as a must.

In choosing the texts to be analysed in this paper, I focus on the celebrities who appeared and reappeared in Cover Story at least three times within the period of 2000-2006. This is to establish a sense of continuity of the narrative of the selves within the different moments of their lives. There are two celebrities that appeared in four issues, namely Putri Patricia and Feby Febiola. Four others appeared in three issues, and I chose two out of these as their appearances take the longer time span. Falling into this category are Mariana Renata (February, 2000 - September, 2005) and Alya Rohali (November, 2000 - June, 2006). I propose that the longer time covered, the fuller the segments and moments of the life can be revealed. I also argue that a longer time span means a more sense of continuity, despite the time discrepancy and disruptions. In other words, the texts provide what Pearce (1994: 193) argues as "fragmented temporal continuum".

\section{COVER STORY: CHRONOTOPIC REPRESENTATIONS OF FEMININE SELVES}

In this part I examine the structure of Cover Story and how the structuring of the story contributes to the construction of the female celebrities' femininity in a way that constitute both fragments and coherence. The fragments and the coherence is consistent with the structuring of women's magazine, which Cixous (1981) argues to be both partial and whole, fragmented yet coherent. Cover Story is comprised of three basic parts, namely the title, the introduction and the body.
Figure 1

Mariana Renata

Cover Story 2000

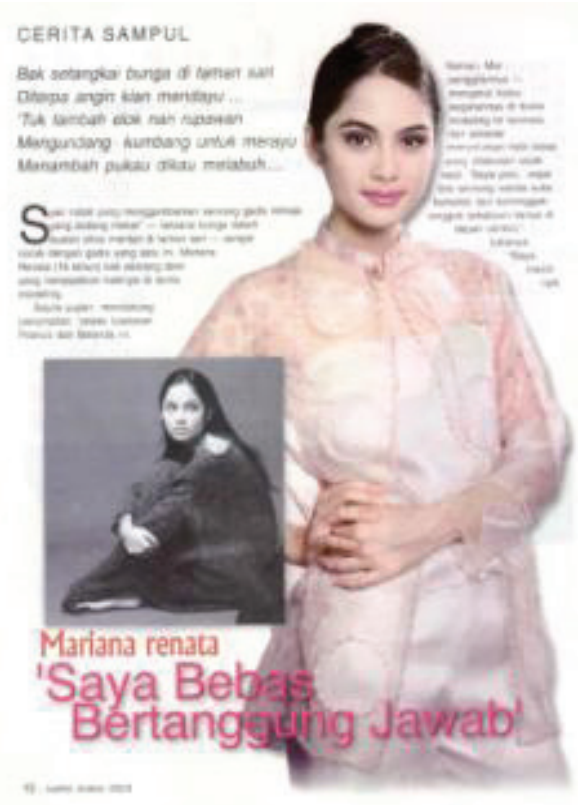

Figure 2

Feby Febiola

Cover Story 2006

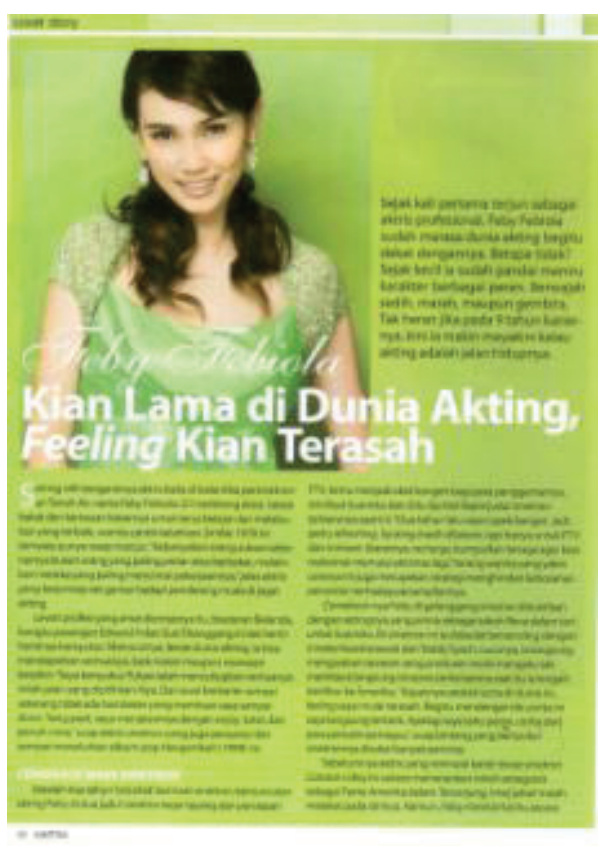


The title usually consists of two parts, namely the name of the celebrity and a short line of direct quotation from the interview or a "summary" of the viewpoint of the celebrity, the form of which can be in direct speech or indirect speech and point to a key theme of the text. Some examples are the followings

Figure 1:

Mariana Renata: "I am free but responsible"1

Figure 2:

Feby Febiola: The more [I am] in the acting world, the more [my] feeling gets sharpened

Both pieces of text imply an auto/biographical subject, articulating her perspective on her life as a celebrity.

The title may or may not reflect the whole text as the title also functions to attract the readers. The second part of Cover Story structure is the introduction. The introduction functions as an abstract of the text. It reminds the readers of the celebrity featured by stating her status in terms of her achievement, her past or present relationships, as well as her point of view on certain issues, mostly pertaining to their personal opinion and preferences. The following are typical introductions of the two figures (Figure 1 and Figure 2)

Figure 1:

Like a stem of flower in a flower garden Blown by the wind, it grew prettier....

For it became more beautiful and delightful

It invited the bees to seduce...

It augments charm where you land...

Figure 2:

Since the first time she became a professional actress, Feby Febiola felt that acting world was very close to her. Why not? Since she was a little girl, she had been good at mimicking characters and playing various roles. Putting on a sad, angry, or happy face. Small wonder that in 9 years of her career, now she is more convinced that acting is her path of life.

In Figure 1, the introduction is a poem describing the beauty of the celebrity featured (Mariana Renata). The narrative consequently describes her beauty, her career, and how she is becoming a famous model in Indonesia. In Figure 5.2, the introduction points to Feby's acting ability which was noticed at a very early age; her success is to be considered as a natural.

The third part of the structure is the body text. In this part celebrity's life is told in third person narrative. The striking feature of celebrity profile in Cover Story is the extensive use of flashback to situate the celebrity featured into the present situation. Despite the fact that the celebrities are not the narrators, direct quotations are constantly used as part of the narrative. The following is a sample passage from Feby Febiola's Cover Story (M.R., 2000: 10)

Recently, many people have been feeling infuriated by Febby Febiola. It's just because every time she appears on the television, she is always the jealous and evil girl. On Wednesday nights, she appears as Rena, the egocentric and envious girl in "Tersayang”, On Friday nights she appears as "Tante Amerika" who is indescribably evil. "I am bored being an evil character," said the actress whose actual name is just Febiola. "In short, it's just boring."

In this passage, Feby the auto/biographical subject is identified as the role she plays in television series and understood through this work. This identification to some extent implies her success in creating the character in her television serials. She however imparts that she is bored with the role. This leads to the question as uttered by the narrator, "If you're bored, why not protest against it, Feby?" (M.R., 2000: 11). The answer is provided by Feby's mother, again replicating the multiple voice strategies of the full-length auto/ biographical texts (M.R., 2000: 11):

Her mother, Mrs Susi Sitanggang, who was accompanying her daughter in the interview with Kartini, joined in. "Actually Febby has been frequently complaining. Every day in the shooting location, she complains, 
but because they [Multivision] ask for her favour, so yeah..." Said Mrs Susi, lifting her shoulders and did not finish her words..."

The passage shows how Feby the auto/biographical subject is being created using different voices, some of whom are "witnesses", namely other characters in the text, and the auto/biographical subject herself. I argue that the while the narrative structure of Cover Story is fragmented, the fragmentations actually work to create and complete the relevant auto/biographical subject. The fragmentations do not only originate from the magazine structure but also in the temporal dislocations of the auto/biographical subject. As the analysis of the book-length auto/biographies and this passage in Feby Febiola's text show, this form of feminine auto/biographical subject is constructed by the integration of others' views and the voices of their partners and families.

In the case of auto/biographical practice in women's magazines, flashback is used to position the celebrity featured within the space and time in the past and connect it to the space and time of the present in such a way that a distance is exposed but at the same time it shows the distance covered; the journey from her pre-celebrity selves to the celebrity selves. The flashback typically consists of these two types of memory, the private and the public. The private indicates the personal memory of the celebrity about her "past" time and her past space denoting her pre-celebrity selves. On the contrary, public memory work is mostly carried out by the narrator who deliberately states the time and space connecting them with event[s] that became the trajectory of the celebrity status of the celebrity featured. The memory presented is not only that of the personal time and space, for example what the celebrity remembers as her past but also it includes the memory built in public space and time, for example in relation to the occurrence of [an] event[s]. In this way the personal time and space meet public time and space.

As Cosslett et.al. (Cosslett, Lury, \& Summerfield, 2000: 5) argue, "Memory, too, then is intersubjective and dialogical, a function of personal idenfications and social commitments. While it may be uniquely ours it is also objectified, a matter of public convention and shared rituals." Thus, the narrator's narrative constitutes a public memory work that refers to public space and time. Wise calls this space "historical space and time", history being interpreted as public memory of a public[ized] occurrence.

In Cover Story, where flashback is used, the narrator starts the story by moving the time space to the past, giving the account about the beginning of the featured celebrity's career - in two of the four celebrities discussed in this paper emphasize the unplanned, accidental and surprising (unexpected) nature of the beginning or progress of the career. This account is stated both through direct quotations as well as the narrator's narration. Putri Patricia's statement is exemplary of the direct statement about accidental nature of the beginning of celebrity's career. She is quoted, "I was just passing the time. When I was in secondary school, I liked being photographed" (Drianurmini, 2001: 16). The accidental and unexpected nature is also referred to by statements inferring that she "did not mean to do it" or "did not actually want to do $i t$ " or that she was surprised to know that she got the job, as displayed in Mariana Renata's two texts (Simarmata, 2004: 20; Sukmaraja, 2000: 11). The same message of accidental beginning, as well as good luck are stated in the text, as in the account of Putri Patricia's career (Widuhung, 2005) and also that of Mariana Renata, who is said to have been tapped by "the goddess of fortune" (Sukmaraja, 2000: 11).

The reference to accidental luck is symptomatic of celebrity culture that renders celebrities asordinary and extraordinary (Dyer, 2001; Redmond, 2006). But as also seen in the further depiction of the celebrities concerned, luck itself is not enough. They have to prove their "worthiness" of their luck through "hard work and professionalism" as Dyer (2001: 42) asserts:

Particularly as developed in the star system, the success myth tries to orchestrate several contradictory elements: that ordinariness is the hallmark of the star; that the system rewards talent and 'specialness'; that luck, 'breaks', which may happen to anyone typify the career of the star; and that hard 
work and professionalism are necessary for stardom.

This narrative of luck is designated within the space of pre-celebrity and past time. The present celebrity status renders the celebrity a new space for recognition in the present and the future time. This crisscross between the pre-celebrity to celebrity status, from the present and future also highlight the blurring hegemonic space of ordinary and extraordinary. For one ordinary individual to be extraordinary, one needs not only luck but also some extraordinariness and to remain extraordinary, once one has become so, one has to remain ordinary. Extraordinariness in celebrity can manifest in different forms. In Alya Rohali, for example, it is in her being selective in choosing her career path "unlike other actresses", in her pursue of postgraduate study, in her breastfeeding her baby, and her ideal marriage to her husband (then) (Drianurmini, 2000).

In Feby Febiola, her distinction from the rest (the other ordinaries and other celebrities) is her "professionalism", which includes playing the typical and becoming boring role in a television cinema, her expansion of career path to singing in addition to modelling, which has been her profession earlier (M.R., 2000). As the story moves its chronotope to the present, these ideals remain the same regardless the fact that between the year of 2000 to 2006, for example, in her real-life Alya Rohali has experienced different obstacles and changes, including divorce, which changed her status from a married woman to a single mother. These, particularly painful transformation is not visible either in the picture or in narration. Her pictures of 2000 and 2006 are equally radiant and optimistic. She does not seem to age despite the 6 year gap of her first feature in the magazine. Her ideals and view towards her partner remain the same and her feeling for her current partner, who is not the same one she had in 2000, is as adoring as it was for her previous partner. The issue in 2003 acts as a gap between the two spaces of her romantic relationships, yet this issue only produces segments of life, selected moments when the pain has subsided and other negative feelings have been overcome.
In the Cover Story in 2000 (Figure.3), Alia says (Drianurmini, 2000: 23):

"Mas Eri is not fussy. We always communicate. I always talk to him about what I will do, and usually he agrees. About children, we agree to have three. It doesn't matter whether it's a boy or a girl"'

In the Cover Story in 2006 (Figure 4), Alya talks about her new partner: "Although he is older than me, he is funny, easy going, decisive, understanding, humble, what else... " (Yudha \& GD, 2006: 10) In the issue in 2003, Alya Rohali is depicted as a single parent with no partner. This issue acts as a bridge between the two spaces of the romantic relationships and marriages in 2000 and in 2006. The 2003 issue still presents her as a happy strong woman who has completely taken everything under control and has adapted well to the new situation. As the narrator says, "that there is no reason [for her] to be hostile with her exhusband" (Paramita, 2003).

Figure 3

Alya Rohali

Cover Story, 2000

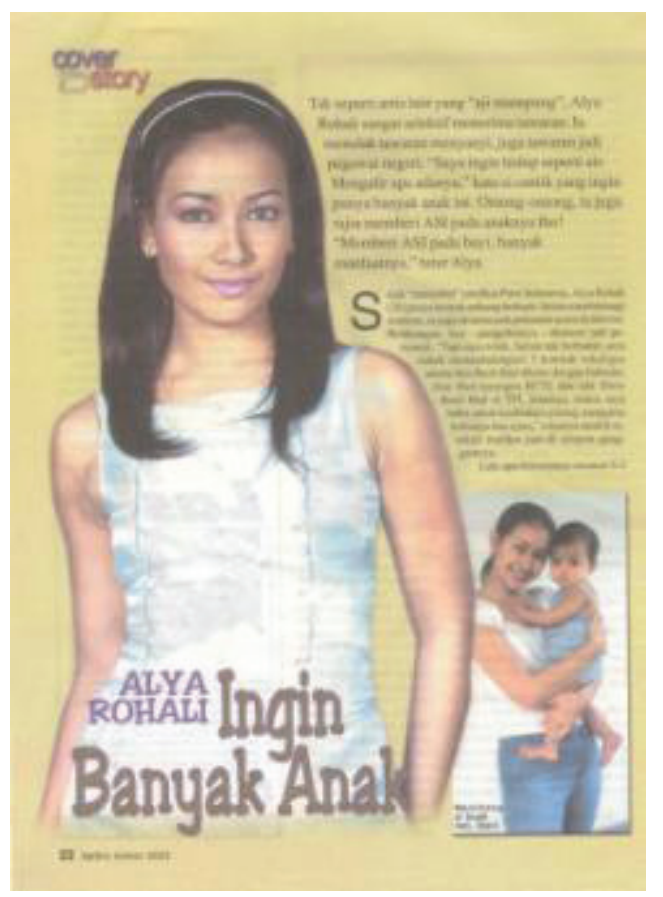




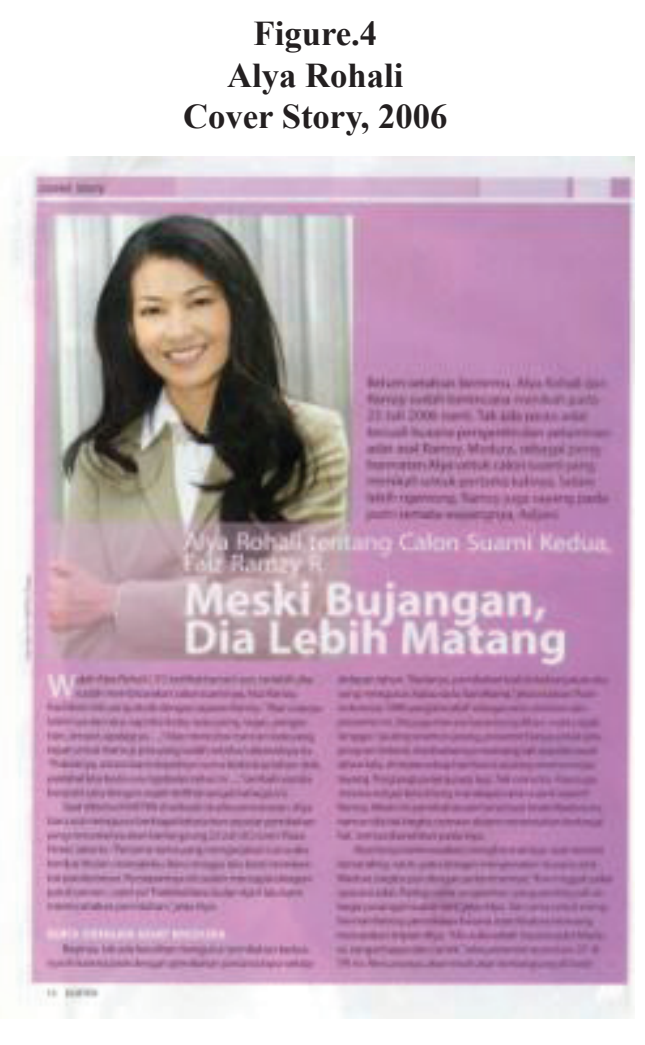

The constant references to happy relationships with her husband, ex husband, and future husband, as particularly apparent in Alya Rohali's narratives (Drianurmini, 2000; Paramita, 2003; Yudha \& GD, 2006) signify the centrality of relationships to normative femininity in these auto/biographical texts in magazines. The same pattern can be observed with Feby Febiola, who was with one man in the first Cover Story but later married another man (Anton, 2004; M.R., 2000; Rinawati, 2006; Sukmaraja, 2002).

Feby Febiola's relationships with different men (her former boyfriend and her husband) are always described as happy ones. Following her assertions of privacy, she describes how she fell in love with her then boyfriend and even lamented the Valentine's day she had to spend without him (M.R., 2000). In Cover Story in 2002, Feby and her husband are described as harmonious and understanding towards each other and their marriage is idealized and romanticized: "The young handsome and beautiful couple seem to love each other... He was so caring and full of attention" (Sukmaraja, 2002: 28). In another issue, Feby directly comments on her marriage: "Marriage is basically a process of uniting two persons. So, it takes a learning process [for us] to be harmonious... Basically, we just need to get a long [sic] well" (Anton, 2004: 20-22). The portrayal of idealized celebrity femininity relies upon these narratives of happy relationships.

It can be argued that the celebrities are shown to have the normative embodiment of ideal femininity: beautiful, and remains beautiful over the years. In the case of Alya Rohali, she has a body that remains slim even after childbirth. The reference to beauty is actually a prototypical characteristic of celebrity auto/biographical practice in women's magazines. All women are referred to as being "beautiful" in some parts of their portrayals, particularly in the introduction or in the first paragraphs. The typical narrative about beauty in Cover Story is by referring to the celebrity as "the beautiful woman", such as in the following example in the text on Mariana Renata, "Finally, after a few meetings and interviews, the beautiful girl who was born on 31 December 1983 officially became the model of LUX" (Simarmata, 2004). The consistent denotation of "beautiful girl/woman" suggests that being beautiful is the primary reference of their embodiment of their celebrity status.

The reference to doing a University degree as an important thing in the construction of femininity as intelligence is also found in Mariana Renata's narrative (Simarmata, 2004). Intelligence does not merely refer to the academic capacity but more importantly to the ability for multitasking, to be different selves, taking different spaces at the same time. Thus again, time is condensed while the space is extended. The ability to negotiate such chronotope can be considered not only as the representation of idealized feminine selves but also the extraordinary characteristic of their celebrity selves.

As I have hinted, the normative portrayal is heavily emphasized by the constant reference to happy relationships with spouses, ex-spouses, and future spouses or husbands, as particularly apparent in Alya Rohali's narrative (Drianurmini, 2000; Paramita, 2003; Yudha \& GD, 2006). The same can be said about another married celebrity, Feby Febiola, who was with another man at the first 
Cover Story but later married another man (Anton, 2004; M.R., 2000; Rinawati, 2006; Sukmaraja, 2002). In Feby Febiola's narrative, married-life is described as happy. The couple is described as harmonious and understanding towards each other in the way that their marriage is idealized and romanticised. The private space of marriage is put as a public display, as a performance, yet it constructs her not entirely as a public person, rather as a private person deliberately put in public stage. Her private life becomes the "public square" in which the supposedly personal deliberations about relationship are delivered. Feby Febiola the public self and Feby Febiola the personal self thus substitute each other the ways in which it renders the competing idealized images of her [private] femininity self and [public] celebrity self which she has supposedly succeeded to be displayed.

In all selected texts of Cover Story, these auto/biographical subjects submit to this ideal of normative femininity and heterosexuality, but at the same time there are small challenges allowed in references to their capability for independence away from their liaisons with men. They perform the expected role of being a woman in their relationship by constantly referring to their [future] partners or their need for them, even as they demonstrate their independence (Ussher, 1997). The Cover Story texts persistently discuss the issue of happy heterosexual relationships, even when dealing with the absence of partner by referring to what is expected from her [future] man, as in the case of Mariana Renata (Ikrima, 2005; Simarmata, 2004) and Putri Patricia (Drianurmini, 2001), or by referring to the insistence of keeping her private life private. The irony of such a depiction is that the story about the absence of men is used to substitute for the story about the man they are supposedly in a relationship with. Likewise, the frequently quoted insistence on "keeping things private" while at the same time telling the story of the particular celebrity relationship, as in the case of Putri Patricia (Sukamaraja \& Melly, 2003) and Feby Febiola (M.R., 2000) even when nominally absent, shows that celebrity femininity in women's magazines is highly dependent on heterosexuality,

Particular mentions of overcoming crisis and difficulties and the re-emergence as both a new and the same idealized feminine Selves through changes can be found in all narratives of celebrities analysed in this section. In particular is that of Alya Rohali's as I have discussed. Another example is the narrative of Feby Febiola. Her narrative includes a flashback about her past pre-celebrity status ( 9 years of biographical age), where she started as a mere teenage model to the time when she has become an established actress. Her present biographical selves is portrayed as a very humble person, as other non-celebrities are supposed to be. This is contrasted to her supposedly established status as an actor as highlighted in the title of this particular text, "The more [I am] in the acting world, my feeling is getting more sharpened" (Rinawati, 2006: 10). This title suggests Feby Febiola's established status as an actor but at the same time her biographical selves explicitly articulate that her acting career is a mere "ordinary experience" because she is "used to acting". These opposing stands again insinuate the traverse of the two celebrity domains of ordinary and extraordinary. Acting is described as work (that needs to be sharpened) but at the same time, it is also represented as her natural talent (that she can do without having to exert much effort). I argue that in this portrayal, Feby Febiola is pictured and constructed as an ordinary person who happens to have extra - ordinary quality or an extraordinary person who happens to be ordinary. In short, she is represented as an ordinary extraordinary person, or an extraordinary ordinary person. These differentiation is important because a celebrity is supposedly an ordinary person, yet she/he has an extraordinary talent that eventually makes her/him extraordinary (Marshall, 2001). In addition, there is also the assumption that basically, a celebrity is born extraordinary, as the narrative of accidental beginning of various celebrities have shown (McCracken, 1993). Their extraordinariness is just something waiting to emerge from their ordinariness.

The traversing of chronotopes is more obvious in the photographic narratives in all cases of the portrayals of the celebrities in Cover Story investigated in this paper. All four celebrities do not age in all their photographs throughout the years covered. Despite the elapse of five to six years, the four celebrities remain as youthful as their first appearance in the cover story. Even more 
interesting, for example, due to the different trends of what are fashionable regarding the dress, make up, hairstyle, choreograph, etc. within certain spaces and times, I argue that in their photographs, Putri Patricia and Alya Rohali somehow even age in reverse. That is, they look older in photographs of their first appearance than in their later appearance. This also shows how the "story" of celebrities in magazine falls into the category of romantic chronotope as Pearce (1998) coins.

Having looked into parts of the narrative of "fragmented temporal continuum" (Pearce, 1994: 193) in Cover Story, I argue that the auto/biography of celebrities is almost always the representation of the idealized feminine selves capable of transcending time, challenges and crises, the selves who are continuously and simultaneously the same and the new persons, and whose struggle and efforts for success and survival leave no trace of time elapsed or excess of distress. The selective and carefully chosen moments of their lives considered fit to represent their selves constitute the representation of their ideal[ized] Selves. As Bakhtin (1981: 131) argues, "Real biographical time is here almost entirely dissolved in the ideal (and even abstract) time of metamorphosis". In other words, the "real and truthful" selves is not to be found in auto/biographies.

In the Cover Story featuring Alya Rohali,(Drianurmini, 2000), the portrayal of her celebrity self is displayed through the memory work used in flashback by reciting public or historical events in which the celebrity has made her trajectory or breakthrough to success. In the story of Alya, the narrator starts the story by reminding the readers about the Putri Indonesia pageant $^{2}$ that Alya won in 1996. The narrator then continues by mentioning programs and films that Alya Rohali has starred. As public events, the programs and films become the representation of Alya Rohali as a public self in public time and space. Interestingly this representation of public self is then juxtaposed with her own narrative telling about her private self at that time that she began her career, particularly her difficulty in juggling with her public and private commitments, "[A]t that time, my whole time was spent on shooting, taking care of the family and exams" (Drianurmini, 2000: 22). This utterance shows how time and space produce a complicated web of the construction of her differing/different feminine selves. Not only Alya Rohali is fragmented between the past and the present selves, she is also fragmented in her position in private and public spaces: Alya Rohali the celebrity, the mother/ wife and the student. The construction of selves is thus fragmented among the different spaces whose boundary of public and private is blurred. Her celebrity status renders her personal space to be put in public, making her performance as a feminine selves put doubly in display, as a we can see, for example in the photograph of her holding her daughter. In this picture she is dressed very casually, denoting the position of that moment as private, yet this private space is displayed in public space, making it public.

The representation of the selves as a public memory is also shown in Feby Febiola's Cover Story, where her celebrity status is closely associated with a highly successful movie in 1980s, Catatan Si Boy. This trajectory of career is mentioned in the Cover Story of two issues (Anton, 2004; Sukmaraja, 2002), denoting the importance of the public success of Catatan Si Boy to the individual career of Feby Febiola. Interestingly, the first paragraphs of the bodies of the feature are identical in representing Feby Febiola as both a private and public selves. The paragraphs both represent Feby Febiola as a pretty actress, mentioning further her origin, "born in Jakarta" her age by either mentioning the exact date of birth, including the year or by stating her age, "born 24 years ago" (in 2002). The description then goes on to her role in Catatan Si Boy, yet emphasizing it that she only became famous after her role in television series Tersayang.

This public memory work presents a very interesting construction of her feminine selves through the chronotopes of the narratives. I argue that the association is established to ignite the public memory of her role in the film. Thus the construction of her celebrity status is not only dependant on what she does, but also on historical events in which she participated. The readers are invited to associate the public event to the more private occurrence in the life of Feby Febiola. Again, the construction of female celebrity private space is in dialogue with, if not substituted by, the public space. 
After associating her past with a "historical" event, the narrative moves again to private space as it tells about her parents, highlighting her mixedrace origin (she has Dutch origin). However, even this personal embodiment is inevitably public for first it is publicised, deliberated in a public space, and it cannot be dissociated from Indonesian context: culture and history. Being mixed-race (of white descent) is an advantage in Indonesian culture, particularly in popular and women's culture. Out of the four celebrities discussed here, two are mixed-raced, namely Feby Febiola and Mariana Renata (of French, Japanese and Italian descent). In fact, mixed-raced celebrities are a prevalent phenomenon in Asian popular culture, especially in Indonesia as I have argued elsewhere (Prabasmoro, 2004, 2006). Further than that, as whiteness is signified as beautiful and attractive, it further renders more emergence of mixed-raced celebrities making it more and more of idealized beauty (Prabasmoro, 2004). This deliberation reveals that the construct of Indonesian women's beauty and desirability is not exclusive within the local space and/or contemporary time, rather it is deeply rooted in the issue of race, ethnic, as well global construct of white femininity that in the case of Indonesia can be traced long back to the past during or as the effect of the Dutch colonialization (Prabasmoro, 2004).

\section{REPRESENTATION OF BEAUTY, BODY IN THE PHOTOGRAPHIC NARRATIVE}

In this part of the discussion, I elaborate how the photographic narrative of the article construct beauty and body in a way that upholds the idea of normative femininity, marked significantly by youthful beauty and ideal body that transgress chronological time. As having been pointed out by varied researches, including my previous researches on celebrity (Priyatna, 2013) beauty, the slender youthful body and the capacity to hold back time are critical aspects of celebrity femininity. These celebrities do not age in all their photographs throughout the years covered. Despite the elapsing of five to six years, the four celebrities remain as youthful in their first appearance in the cover story as they do in their last. Even more interesting, some seem to age in reverse. This is observable in the images of Putri Patricia in the cover story dated 2001.2003, 2005, and 2006. The same can also be argued for the images of Feby Febiola dated 2000, 2002, 2004, and 2006. Both Putri Patricia and Feby Febiola look as young as, if not younger than when they appeared in the first Cover Story. These temporal dislocations and collapses are important in creating cohering auto/ biographical subjects that maintain their beauty and create an idealized celebrity femininity which is capable of transcending time, challenges and crises and resisting the processes of ageing, as occurred in the full-length auto/biographical texts.

In all of these selected texts, the celebrities are presented within the confines of a normative embodiment of ideal femininity: beautiful, and remaining beautiful over the years. Particularly in the case of Alya Rohali (Drianurmini, 2000; Yudha \& GD, 2006), who is the only mother among the four celebrities discussed in this section, no traces of physical transformation are visible. All these auto/ biographical subjects are referred to as "beautiful" in some parts of their portrayals, particularly in the introduction or in the first paragraphs. The typical narrative is as reflected in the following example in the text on Mariana Renata, "Finally, after a few meetings and interviews, the beautiful girl who was born on 31 December 1983 officially became the model of LUX" (Simarmata, 2004: 20). The celebrities are also described based on their heights and weights, such as "the owner of $175 \mathrm{~cm}$ and 51 kg body" for Mariana Renata (Sukmaraja, 2000: 11 ) and "the pretty girl, the owner of $165 \mathrm{~cm}$ height and $45 \mathrm{~kg}$ weight..." for Putri Patricia (Widuhung, 2005). The consistent denotation of "beautiful girl/ woman" suggests that being beautiful is key to their celebrity status.

I propose that these pieces operate as "new forms" of auto/biography within celebrity and women's culture which adapt and alter conventional practices of auto/biographical narration to suit the short and fractured formats in these magazines. However, the themes of beauty, opportunity and dedication to heterosexual love present in the longer forms are also key in these new forms, in the creation of cohering and consistent subject positions in particular. The newness of these forms of celebrity auto/biographical practice is thus not much in their content but, rather, in their form of expression. 


\section{CONCLUSION}

Having looked into the temporal auto/biographies of female celebrities in magazine, I propose that female celebrities are constantly linked to their personal domains regardless of their contribution in public space. Thus, while these auto/biographical practice can be said to have attempted different representations of femininity (or femininities) through traversing times and spaces, it highlights again and again the hegemonic construct of masculine and feminine space and time. This again indicates that in auto/biographical practice in women's magazines, female celebrities move continuously between the private space and the public space. Time in such auto/biographical practice is "thickened", the past selves are compressed as historical moments or selective memory but at the same time, the present selves are also represented only by moments evolving around particular issues: physicality (beauty), personal/romantic relationships, and works.

The notion of space is important in the stories of the celebrities as they move from one place to another in conjunction with their career. Thus, their becoming of feminine and celebrity selves is very closely framed within space and time. The story of their lives can be appropriately attributed to these movements as well as their ability to travel between spaces and time. Thus, I can argue that if the whole story is "the life", the chapters are the moments of life that may conclude at the space and time given, but at the same time, once this moment is framed in a bigger space and time, it begins to make sense in the making of the selves of the celebrities. Their identity, sense of self as well as femininity are a continuous process of becoming. While they are portrayed to have somehow reached a certain equilibrium; a stage of peace and satisfaction, they are still pictured to continue transforming. In all cases, female celebrities are portrayed as fragmented but at the same time coherent through the narrative of the auto/biographical practice of Cover Story.

\section{ENDNOTE}

1 I translated the original text in Bahasa Indonesia into English and mark it by italics.

2 There are two competing beauty pageants in Indonesia sponsored by two competing traditional cosmetic companies, one is Putri Indonesia (literally means Miss Indonesia), which is sponsored by Mustika Ratu, the other one is Miss Indonesia, which is sponsored by Sari Ayu. While Putri Indonesia is globally linked to Miss Universe Pageant - thus also referred to as Miss Indonesia Universe, Miss Indonesia is linked to Miss World - thus also referred to as Miss Indonesia World.("Putri Indonesia,").

\section{REFERENCES}

Anton. (2004, 5 - 19 August ). Feby Febiola: "Rencananya, Punya Momongan Dua Tahun Lagi”. Kartini, 20-22.

Bakhtin, M. M. (1981). The Dialogic Imagination: Four Essays by M.M. Bakhtin (C. Emerson \& M. Holquist, Trans.). In M. Holquist (Ed.). Austin: University of Texas Press.

Bordo, S. (1995). Reading the Slender Body Unbearable Weight: Feminism, Western Culture, and the Body (pp. 185-212). Berkeley, Los Angeles, London: University of California Press.

Cixous, H. (1981). The Laugh of the Medusa. In E. Marks \& I. deCourtivron (Eds.), New French Feminisms: An Anthology (pp. 245-264). New York: Schocken Books.

Cosslett, T., Lury, C., \& Summerfield, P. (Eds.). (2000). Feminism and Autobiography: Text, Theories, Methods. London, New York Routledge.

Davis, K. (1995). Beauty and the Female Body Reshaping the Female Body: the Dilemma of Cosmetic Surgery (pp. 39-67): Routledge.

Drianurmini, S. R. (2000, 16 - 30 November). Alya Rohali: Ingin Banyak Anak. Kartini, 22-23.

Drianurmini, S. R. (2001, 15 - 29 March 2001). Patricia Ayu Dewayani: Suka Yang Mirip Frans Lingua. Kartini, 16 - 17.

Dyer, R. (2001). Stars. London: British Film Institute Publishing.

Ikrima. (2005, 29 September - 13 October). Mariana Renata: Semua Orang Tidak Sempurna. Kartini.

Jelinek, E. C. (1998). Women's Autobiography: Essays in Criticism. In S. Smith \& J. Watson (Eds.), Women, Autobiography and Theory: A Reader. London: The University of Wisconsin Press.

Kartajaya, H., Yuswohady, Christynar, M. M., \& Darwin, W. (2005). Winning the Mom Market in Indonesia: Strategi Membidik Pasar Ibu. Jakarta: MarkPlus \& Co. 
Kasali, R. (1998). Membidik Pasar Indonesia: Segmentasi, Targeting, dan Positioning (2nd ed.). Jakarta: Gramedia Pustaka Utama.

M.R., P. D. (2000, 2 - 6 March). Febi Febiola: "Saya Bosan Jadi Wanita Jahat”. Kartini, 10-11, 126.

Marcus, L. (1994). Auto/Biographical Discourses: Theory, Criticism, Practice. Manchester and New York: Manchester University Press.

Marshall, D. P. (2001). Celebrity and Power-Fame in Contemporary Culture. Minneapolis, London: University of Minnesota Press.

McCracken, E. (1993). Decoding Women's Magazines: From Mademoiselle to Ms. New York: St Martin's Press.

Paramita, N. (2003, 16-30 October). Alya Rohali: "Harushati-hatidanPintarJagaDiri”.Kartini.

Pearce, L. (1994). Reading Dialogics. London, New York: Edward Arnold.

Pearce, L. (1998). Another Time, Another Place: the Chronotope of Romantic Love in Contemporary Feminist Fiction. In L. Pearce \& G. Wisker (Eds.), Fatal Attractions: Rescripting Romance in Contemporary Literature and Film (pp. 98111). London: Pluto Press.

Prabasmoro, A. P. (2004). Becoming White: Representasi Ras, Kelas, Femininitas dan Globalitas dalam Iklan Sabun. Bandung and Yogyakarta: Jalasutra.

Prabasmoro, A. P. (2006). Putih, Femininitas dan Seksualitas Perempuan dalam Iklan Kita Kajian Budaya Feminis: Tubuh, Sastra, dan Budaya Pop. Bandung: Jalasutra.

Priyatna, A. (2013). Becoming White: Representasi Ras, Kelas, Femininitas dan Globalitas dalam Iklan Sabun. Bandung: Matahari.
Putri Indonesia. from http://www.puteri-indonesia.com/ Redmond, S. (2006). Intimate Fame Everywhere. In S. Holmes \& S. Redmond (Eds.), Framing Celebrity: New Directions in Celebrity Culture (pp. 27-44). London, New York: Routledge.

Rinawati, D. (2006, 27 April - 11 Mei ). Febi Febiola: Kian Lama di Dunia Akting, Feeling Kian Terasah. Kartini, 10, 12.

Shunway, S. R. (1994). The Chronotope of the Asylum: Jane Eyre, Feminism, and Bakhtinian Theory. In K. Hohne \& H. Wussow (Eds.), A Dialogue of Voices: Feminist Literary Theory and Bakhtin. Minneapolis, London: University of Minnesota Press.

Simarmata, H. (2004, 18 March - 1 April 2004). Mariana Renata : Bahagia Jadi Mahasiswa. Kartini.

Sukamaraja, E., \& Melly. (2003). Putri Patricia: Pacarku Bukan dari Kalangan Artis. Kartini, 20-22.

Sukmaraja, E. (2000, 3-17 February 2000). Mariana Renata: "Saya Bebas Bertanggung Jawab". Kartini.

Sukmaraja, E. (2002, December ). Feby Febiola: Mendapat Skenario sebagai Tanda Cinta. Kartini, 26-28.

Ussher, J. M. (1997). Fantasies of Femininity: Reframing the Boundaries of Sex. London: Penguin Books.

Widuhung, S. (2005, 18 August - 1 September 2005). Putri Patricia: Targetkan Nikah Sebelum Usia 30. Kartini, 20-21.

Yudha, \& GD, F. (2006, 22 June - 6 July 2006). Alya Rohali tentang Calon Suami Kedua, Faiz Ramzy R - Meski Bujangan, Dia Lebih Matang. Kartini. 